\title{
36. ICE-RAFTED CRETACEOUS AND TERTIARY FOSSILS IN PLEISTOCENE-PLIOCENE SEDIMENTS, ODP LEG 104, NORWEGIAN SEA ${ }^{1}$
}

\author{
Dorothee Spiegler ${ }^{2}$
}

\begin{abstract}
Ice-rafted fossils of late Cretaceous and Tertiary age were detected in Pleistocene-Pliocene glacially influenced sediments of the Vøring Plateau, eastern Norwegian Sea. The ice-rafted associations contain frequent Inoceramus (Bivalvia) prisms and rare occurrences of both benthic and planktonic foraminifers of Miocene, Oligocene, and Maastrichtian to Campanian age. As source areas, shallow outcrops on the Norwegian Continental Shelf as well as the Greenland Shelf and the North and Baltic Seas have to be considered.
\end{abstract}

\section{INTRODUCTION}

Occurrences of reworked fossils in younger deposits provide a means to detect erosion and transport mechanisms in the sediment record. Bottom-water current erosion in the oceans, downslope mass movements, and glacial activities may be responsible for fossil assemblage remobilization. Evidence of reworking is documented by displaced fossils of Cretaceous and Tertiary age in the glacially influenced sediments of the Vøring Plateau, eastern Norwegian Sea. At ODP Leg 104 Sites 642-644, located on a NW-SE transect off the Norwegian coast (Eldholm, Thiede, Taylor, et al., 1987) (Fig.1), large amounts of glacially influenced sediments were recovered in Hole 642B to $66.70 \mathrm{mbsf}$, in Hole $643 \mathrm{~A}$ to $51.26 \mathrm{mbsf}$, and in Hole $644 \mathrm{~A}$ to $234.90 \mathrm{mbsf}$ (Henrich et al., this volume). These sediments very frequently contain reworked ice-rafted Cretaceous to Tertiary fossils.

In the Norwegian-Greenland Sea the oldest glacial events were dated to be $5 \mathrm{Ma}$ (or even older) from DSDP Leg 38 Sites 336 and 344 (Warnke and Hansen, 1977). According to Berggren (1972), the Leg 38 shipboard party estimated the initiation of glacial conditions at $3 \mathrm{Ma}$. This estimate was based on biostratigraphy without paleomagnetic control. However, sections barren of fossils comprise the first glacial deposits. Hence the age estimates of the onset of glacial conditions at Leg 38 sites were not very reliable. Jansen et al. (unpublished data) and Henrich (this volume) estimate that the first major expansion of the Scandinavian ice sheet occurred about $2.56 \mathrm{Ma}$. The history of glacial/interglacial cycles in the Norwegian Sea during the late Pliocene to Pleistocene and their various glacial, deglacial, and interglacial lithofacies types in Leg 104 sites are analyzed in detail by these authors. During extreme glaciation, continental ice sheets extended onto the Scandinavian shelf, almost reaching the shelf edge. Along the outer shelf extensive iceberg ploughing occurred during deglaciation (Rokoengen et al., 1980). Parts of the ice sheets may have been grounded. Over large areas of the shelf, the Precambrian to Caledonian basement is overlain by Paleozoic to Tertiary sedimentary rocks. Considerable amounts of these shelf sediments may have been incorporated into the basal parts of the continental ice sheet during glacial advances. During deglaciation extensive calving occurred. Icebergs probably contained huge amounts of debris, including frozen mud-

\footnotetext{
${ }^{1}$ Eldholm, O., Thiede, J., Taylor, E., et al., 1989. Proc. ODP, Sci. Results, 104: College Station, TX (Ocean Drilling Program).

2 GEOMAR Research Center for Marine Geosciences at the Christian-Albrechts-University, Wischhofstrasse 1-3, Building 4, D-2300 Kiel 14, Federal Republic of Germany.
}

stones derived from the shelf. The distance and geographical areas to which material incorporated in the icebergs was transported depended upon melting rate of the ice, climatic conditions, and the prevailing ocean current systems.

Age determinations of ice-rafted fossils and the detection of their source regions may help to test this model and also to deduce different drift patterns under variable surface-water circulation systems. Improved understanding of surface currents will aid understanding of the Norwegian Current history. The Norwegian Current, because of its transport of warm Atlantic water, is one of the dominant factors controlling physical and biological features in the Norwegian Sea (Kellogg, 1975, 1977, 1980).

\section{MATERIAL AND METHODS}

The ODP Leg 104 samples used for the study of planktonic foraminifer biostratigraphy of Norwegian Sea sediments (Spiegler and Jansen, this volume) were also used in this study. Sample volumes were $20 \mathrm{~cm}^{3}$. The samples were prepared simply by drying and soaking them in water before washing them on a $63-\mu \mathrm{m}$ screen. The analyses were carried out on the fraction $>125 \mu \mathrm{m}$. The fraction was split and the frequencies of planktonic foraminifers were calculated to $1 \mathrm{~g}$ dry sediment. If icerafted fossils were detected, the rest of the sample was also examined.

The Quaternary stratigraphic framework for Sites 642-644 is mainly based on paleomagnetics (Bleil, this volume). Tentative isotopic stage determinations in Holes 642B and 643A, given in Figure 2, are derived from carbonate stratigraphy (Henrich, this volume) in addition to oxygen isotope results from Jansen et al. (this volume). The odd stages in Hole $644 \mathrm{~A}$ are only calculated. Positions of dark deglaciation layers are reproduced from Henrich (this volume), and Eldholm, Thiede, Taylor, et al. (1987).

\section{RESULTS}

Figure 2 displays records of ice-rafted fossils, absolute numbers of planktonic foraminifers per gram (fraction $>125 \mu \mathrm{m}$ ), and dark lithofacies occurrences in Holes 642B, 643A, and 644A.

The dark layers consist of various deglaciation sediments, either deposited during the major transition from a glacial to an interglacial period or during an initial warming within a glacial period (Henrich, this volume). They contain very high amounts of terrigenous ice-rafted debris as well as densely scattered lithic dropstones, and abundant mud clasts interpreted as frozen mud dropstones. Ice-rafted fossils are observed within, or close to, these dark layers. Additionally, these sections are characterized by less abundant planktonic foraminifers. In contrast, samples with high amounts of planktonic foraminifers do not contain ice-rafted fossils. These features are only seen in the sequences of Hole 644A and in higher levels of Hole 642B and 643A, be- 


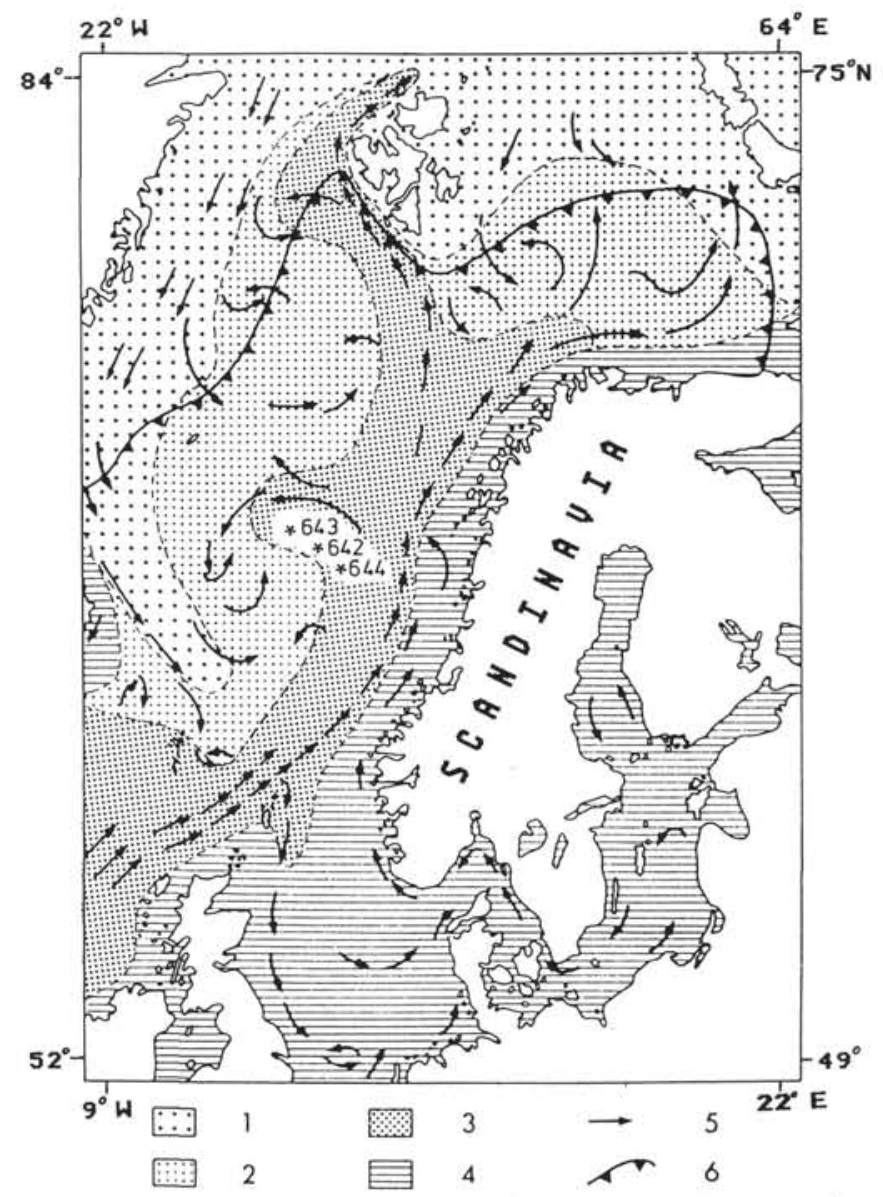

Figure 1. Surface waters and main circulation pattern in the Norwegian Sea and adjoining seas. $1=$ arctic water, $2=$ mixed water, $3=$ Atlantic water in the Norwegian Current, $4=$ coastal-, Baltic-, and North Sea waters, 5 = surface currents, 6 = sea ice border April; * mark Leg 104 sites (from Hald and Vorren, 1987, Mosby, 1968).

cause the sections older than $0.8 \mathrm{Ma}$ in Hole $642 \mathrm{~B}$ and older than 1.15 Ma in Hole 643A are barren of planktonic foraminifers.

Ice-rafted fossils, most frequently Inoceramus (Bivalvia) prisms, but also benthic and planktonic foraminifers, were observed in all three Leg 104 sites. Inoceramus shells are composed of calcitic prismatic layers. The shells usually disintegrate into small prisms during deposition and are frequently found in the coarse fraction of ice-rafted sediments. The genus Inoceramus ranges from Early Jurassic to Maastrichtian in age. In Hole 642B the Inoceramus debris were detected together with typical Late Cretaceous foraminifers. Ice-rafted foraminifers (for occurrences see Tables 1-3) most commonly reveal medium to strong corrosion. Tests show large holes, and chambers are frequently broken off (Plate 1).

\section{Site 642}

In Hole 642B, located on the outer Vøring Plateau, ice-rafted microfossils of Cretaceous and Tertiary age were detected. Occurrences are limited in the Matuyama and more frequent at the Pliocene/Pleistocene boundary. Sediments dated to between 0.5 and $0.3 \mathrm{Ma}$ and younger than stage $7(0.24 \mathrm{Ma})$ contain no icerafted fossils. The noncontemporaneous fossils are mainly enriched in or near the dark layers (Fig. 2). Whereas the deepest sample (104-642B-8-3, $113 \mathrm{~cm}=$ upper Pliocene, above the base of the Matuyama chron) contains mixed ice-rafted fossils of Cretaceous and Miocene age, the younger ones yield either pure Tertiary or Cretaceous markers.
Cretaceous material is mainly documented by Inoceramus prisms, as discussed above. However, in four samples planktonic and benthic foraminifers of Cretaceous age were also observed, which allow age determinations: Sample 104-642B-3-1,116 cm contains Globotruncana bulloides, Bolivinoides decoratus decoratus, Stensioeina incondita, and Globigerinelloides prairiehillensis, typical of Campanian to lower Maastrichtian sediments. In Sample 104-642B-3-2, $44 \mathrm{~cm}$ Heterohelix striata was observed with a distribution of early Campanian to early Maastrichtian and Sample 104-642B-3-2, $106 \mathrm{~cm}$ contains Globotruncana bulloides, also typical of the Campanian to Maastrichtian. Sample 104-642B-5-7, $33 \mathrm{~cm}$ includes Bolivinoides draco miliaris with a distribution of late Campanian to late Maastrichtian age.

Tertiary sediments are documented in three samples. Sample 104-642B-5-3, $74 \mathrm{~cm}$ contains a rich association of planktonic foraminifers with Fohsella peripheroronda, Neogloboquadrina mayeri, Globigerinoides primordius, Globoquadrina dehiscens, Globoturborotalita woodi, Globigerinoides subquadratus, and Globigerinoides trilobus. The fauna is typically for an early Miocene age. The Samples 104-642B-7-3, $20 \mathrm{~cm}$ and -642B-8-3, $113 \mathrm{~cm}$ contain Globigerinoides subquadratus and Globiqerinoides trilobus, both typical of Miocene sediments (Table 1).

\section{Site 643}

In Hole $643 \mathrm{~A}$, located on the lower slope near the base of the Vøring Plateau, displaced fossils are common in the Matuyama as well in the Brunhes sediments. The negative correlation of high planktonic foraminifer numbers and ice-rafted fossils is also documented for Hole 643A samples (Fig. 2).

Inoceramus prisms are common as ice-rafted fossils. Only Sample 104-643A-5-5, $42 \mathrm{~cm}$ contains additional planktonic foraminifers of Oligocene to early Miocene age. The observed Tenuitella clemenciae is typically for Oligocene sediments, whereas Globigerina praebulloides has a long stratigraphic range of late Eocene to middle Miocene (Table 2).

\section{Site 644}

In Hole 644A, located on the inner Vøring Plateau, only Inoceramus prisms were detected as ice-rafted fossils. Their first occurrence is in the upper part of the Olduvai event in a dark layer. Sporadic occurrences are found up to the base of the Jaramillo event, although within the Jaramillo interval no ice-rafted fossils are recorded. Inoceramus prisms commonly occur in connection with the dark layers, being more common in the Brunhes than in the Matuyama interval (Fig. 2, Table 3).

\section{DISCUSSION}

In all three holes the first occurrence of ice-rafted fossils lies above the lowermost observation of glacially influenced sediments. In Hole 642B the first evidence is recorded only $4 \mathrm{~m}$ above the top of the Gauss event in sediments of approximately late Pliocene age (2.2 Ma). Somewhat younger records of icerafted fossils are indicated in Hole 643A at about 2.15 Ma. In Hole 644A the first ice-rafted fossils are recorded at considerably younger levels at about $1.7 \mathrm{Ma}$.

The allochthonous fossils observed in the Pliocene-Pleistocene of the Sites 642 to 644 have been identified as ice-rafted debris. In the glacially influenced sediments of the Hole 642B lower Campanian to lower Maastrichtian is documented by $\mathrm{BO}$ livinoides decoratus decoratus and Stensioeina granulata incondita in Sample 104-642B-31, $116 \mathrm{~cm}$. Upper Campanian to upper Maastrichtian is dated by Bolivinoides draco miliaris in Sample 104-642B-5-7, $33 \mathrm{~cm}$.

This succession of the Cretaceous ice-rafted material in Hole 642B reflects stratigraphically reversed deposition of ice-rafted fossils: earlier Cretaceous fossils are recognized at higher levels and the later Cretaceous fossils at deeper levels. This may indi- 


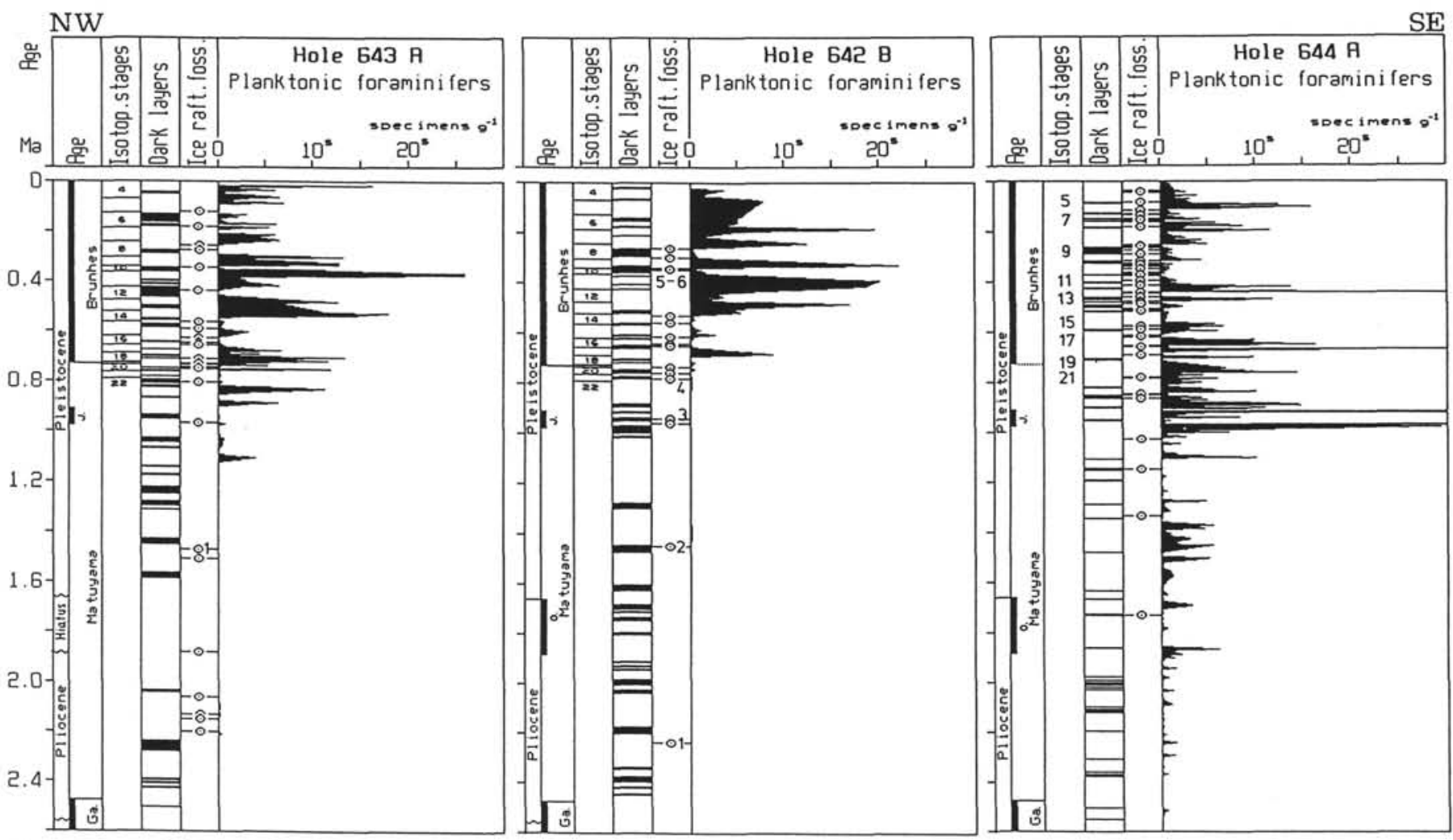

Figure 2. Ice-rafted fossils in Holes 642B, 643A, and 644A and their correlation with age (paleomagnetic anomalies, isotopic stages), dark deglacial lithologies, and abundances of planktonic foraminifers. Age of ice-rafted fossils in 643A: $1=$ Oligocene to early Miocene, unnumbered = Cretaceous; in Hole 642B: 1 = Cretaceous and Miocene, $2=$ Miocene, $3=$ late Campanian to late Maastrichtian, $4=$ early Miocene, 5 and $6=$ early Campanian to early Maastrichtian, unmumbered = Cretaceous; in Hole 644A: only Inoceramus prisms, Cretaceous.

cate successive erosion by ice advance of shallow outcrops from younger to older sediments.

Identification and stratigraphic affiliation of reworked fossils help to delineate the provenance of the sediments in which they were found. This could offer evidence on the paleoceanic current systems and ice-drift trajectories.

Concerning sources for ice-rafted Cretaceous and Tertiary muds and chalks, shallow outcrops and subcrops below a thin Quaternary cover on the Norwegian Continental Shelf provide an important provenance. Bugge et al. (1984) describe Upper Cretaceous assemblages from the mid-Norwegian Continental Shelf rich in planktonic and benthic foraminifers, together with rich occurrences of Inoceramus prisms, similar to the fossil assemblages of ice-rafted debris in Leg 104 holes. Hald and Vorren (1987) describe Weichselian sediments off Troms with icerafted fossils of Quaternary (Eemian) and Cretaceous age. In this paper Cretaceous fossils are assumed to be reworked from nearby Upper Cretaceous rocks. According to Elvsborg (1979), mudrock clasts in glacigenic sediments in the Malangsdjupet are all of Cretaceous age.

In addition to the Norwegian Continental Shelf, other source areas, especially the Greenland Continental Shelf and shallow outcrops in the North or Baltic Seas, must be considered as sources of the allochthonous fossils in Pliocene-Pleistocene sediments. The present initial biostratigraphical data cannot differentiate between these source areas.

\section{CONCLUSIONS}

1. Reworked fossils of late Cretaceous and Tertiary age are detected in upper Cenozoic glacially influenced sediments of the Vøring Plateau.

2. They are ice-rafted fossils.
3. The ice-rafted fossils are composed most frequently of Inoceramus prisms of Cretaceous age and rare benthic and planktonic foraminifers of different ages. The early Campanian to early Maastrichtian is documented by Bolivinoides decoratus decoratus and Stensioeina granulata incondita. The late Campanian to late Maastrichtian is dated by Bolivinoides dracomiliaris. An Oligocene age is verified by Tenuitella clemenciae and early Miocene is proved by Fohsella peripheroronda, Neogloboquadrina mayeri and Globigerinoides primordius. Fossils indicating younger ages are not observed as ice-rafted debris.

4. In Hole 642B the succession of ice-rafted fossils reflects stratigraphically reversed deposition: earlier fossils are recognized at higher levels than the younger ones. This indicates successive erosion from younger to older sediments.

5. Ice-rafted fossils are enriched within or close to dark layers. They contain less abundant planktonic foraminifers. The dark layers are deposited during initial warming periods.

6. Samples with high amounts of planktonic foraminifers, deposited in warm periods, do not contain ice-rafted fossils.

7. Concerning source areas for ice-rafted Cretaceous and Tertiary fossils of the Vøring Plateau, shallow outcrops on the Norwegian Continental Shelf as well as the Greenland Shelf and the North and Baltic Seas have to be considered.

8. A microfaunal distinction between these different source areas is not evident in the present data.

\section{ACKNOWLEDGMENTS}

Sincere thanks are due my colleagues at the Geologisch-Paläontologisches Institut und Museum der Universität Kiel-to R. Henrich and S. Locker for extensive discussions and critical reading of the manuscript, and to A. Freiwald, C. Wieger, B. Rippe, U. Schuldt, and R. Reimann for technical assistance. For helpful critical review I thank H. P. Sejrup and T. O. Vorren. 


\section{REFERENCES}

Berggren, W. A., 1972. Late Pliocene-Pleistocene glaciation. In Laughton, A. S., Berggren, W. A., et al., Init. Repts. DSDP, 12: Washington (U.S. Govt. Printing Office), 953-963.

Bugge, T., Knarud, R., and Mork, A., 1984. Bedrock geology on the mid- Norwegian continental shelf. In Spencer, A. M., et al. (Eds.), Petroleum Geology of the North European Margin: London (Graham \& Trotman), 271-283.

Eldholm, O., Thiede, J., Taylor, E., et al., 1987. Proc. ODP, Init. Repts., 104: College Station, TX (Ocean Drilling Program).

Elvsborg, A., 1979. Late Quaternary sedimentation in a glacial trough on the continental shelf off Troms, northern Norway. Norsk Geol. Tidsskr., 59:308-325.

Hald, M., and Vorren, T. O., 1987. Foraminiferal stratigraphy and environment of late Weichselian deposits on the continental shelf off Troms, northern Norway. Mar. Micropaleontol., 12:129-160.

Kellogg, T.B., 1975. Late Quaternary climatic changes in the Norwegian and Greenland Seas. In Weller, G., and Bowling, S. A., (Eds.): Climate of the Arctic: Palisades, NY (CLIMAP, Lamont-Doharty Geological Observatory, 3-36.

Kellogg, T. B., 1977. Paleoclimatology and Paleoceanography of the Norwegian and Greenland Seas: the last $\mathbf{4 5 0 . 0 0 0}$ years. Mar. Micropaleontol., 2:235-249.

Table 1. Distribution of ice-rafted fossils in Hole 642B.

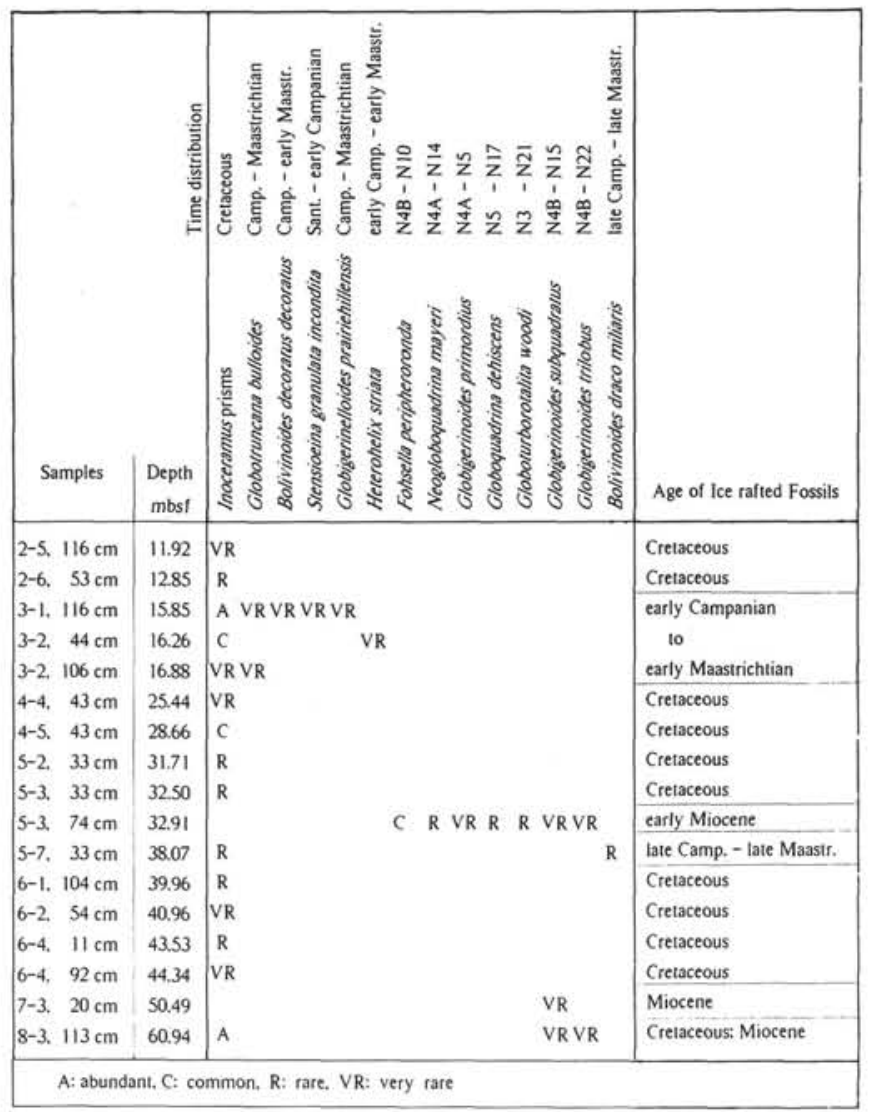

Kellogg, T. B., 1980. Paleoclimatology and Paleoceanography of the Norwegian-Greenland Sea: Glacial-interglacial contrasts. Boreas, 9: 115-137.

Mosby, H., 1968. Surrounding seas. In Somme, A. (Ed.), A Geography of Norden: Oslo, Norway (Cappelens), Map 7, 18-26.

Rokoengen, K., Gunleiksrud, T., Lien, R. L., Lofaldi, M., Rise, L., Sindre, E., Vigram, J. O., 1980. Shallow geology on the continental shelf off Møre and Romsdal. Description of the 1:250,000 Quaternary geological map 6203. IKU Report 105, Trondheim, Norway.

Rokoengen, K., and Saettem, J., 1983. Shallow bedrock Geology and Quaternary thickness off northern Helgeland, Vestfjorden and Lofoten. IKU Report P155, Trondheim, Norway, 1-44.

Warnke, D. A., and Hansen, M. E., 1977. Sediments of glacial origin in the area of operations of D.S.D.P. Leg 38 (Norwegian-Greenland Seas): Preliminary results from Sites 336 and 344. Ber. Naturforsch. Ges. Freiburg i. Br., 67:371-392.

Date of initial receipt: 14 January 1988

Date of acceptance: 4 June 1988

Ms 104B-197

Table 2. Distribution of ice-rafted fossils in Hole 643A.

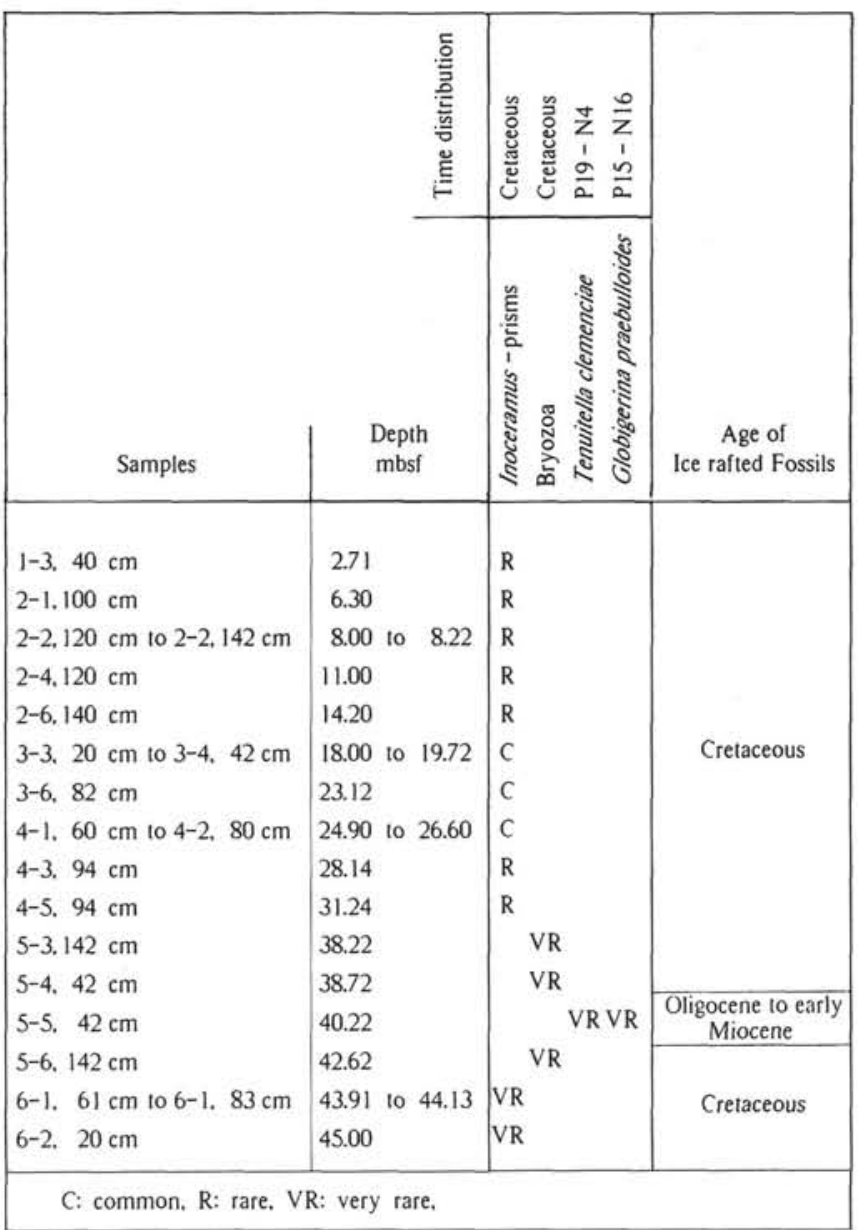


Table 3. Distribution of ice-rafted fossils in Hole 644A.

\begin{tabular}{|c|c|c|c|}
\hline Samples & $\begin{array}{c}\text { Depth } \\
\text { mbsf }\end{array}$ & 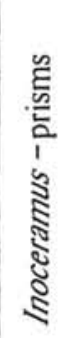 & 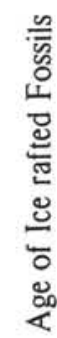 \\
\hline $1-3,144 \mathrm{~cm}$ to $1-4,122 \mathrm{~cm}$ & 4.42 to 5.72 & $\mathrm{R}$ & \\
\hline $2-1,22 \mathrm{~cm}$ to $2-1,62 \mathrm{~cm}$ & 9.42 to 9.82 & $\mathrm{R}$ & \\
\hline $2-3,104 \mathrm{~cm}$ to $2-5,42 \mathrm{~cm}$ & 13.22 to 15.62 & $\mathrm{R}$ & \\
\hline $3-1.82 \mathrm{~cm}$ to $3-2.62 \mathrm{~cm}$ & 17.02 to 18.32 & $\mathrm{C}$ & \\
\hline $3-4,22 \mathrm{~cm}$ & 20.42 & $\mathrm{R}$ & \\
\hline $4-2,122 \mathrm{~cm}$ & 28.40 & $\mathrm{R}$ & \\
\hline $4-3,62 \mathrm{~cm}$ to $4-4,22 \mathrm{~cm}$ & 29.32 to 30.42 & $\mathrm{R}$ & \\
\hline $4-4,102 \mathrm{~cm}$ & 31.22 & $\mathrm{R}$ & \\
\hline $4-5,82 \mathrm{~cm}$ to $5-3,82 \mathrm{~cm}$ & 32.52 to 29.22 & $\mathrm{R}$ & \\
\hline $5-4,42 \mathrm{~cm}$ & 40.12 & $\mathrm{R}$ & \\
\hline $5-4,137 \mathrm{~cm}$ to $6-2,101 \mathrm{~cm}$ & 41.07 to 47.25 & $\mathrm{R}$ & ठํํำ \\
\hline $6-5,22 \mathrm{~cm}$ to $8-1,21 \mathrm{~cm}$ & 50.12 to 63.91 & $\mathrm{R}$ & త్త్ర \\
\hline $8-3,40 \mathrm{~cm}$ & 67.11 & $\mathrm{R}$ & 5 \\
\hline $8-5,22 \mathrm{~cm}$ to $8-5,122 \mathrm{~cm}$ & 69.92 to 70.92 & $\mathrm{R}$ & \\
\hline $9-1,142 \mathrm{~cm}$ to $9-2,40 \mathrm{~cm}$ & 74.62 to 75.10 & $\mathrm{R}$ & \\
\hline $9-4,40 \mathrm{~cm}$ & 78.60 & $\mathrm{R}$ & \\
\hline $10-4,121 \mathrm{~cm}$ to $10-5,21 \mathrm{~cm}$ & 88.41 to 88.91 & $\mathrm{R}$ & \\
\hline $11-3,100 \mathrm{~cm}$ to $11-3,142 \mathrm{~cm}$ & 96.20 to 96.62 & $\mathrm{R}$ & \\
\hline $11-4,122 \mathrm{~cm}$ & 97.92 & VR & \\
\hline $13-3.145 \mathrm{~cm}$ & 114.58 & VR & \\
\hline $14-2,41 \mathrm{~cm}$ & 131.61 & VR & \\
\hline $15-6,42 \mathrm{~cm}$ & 138.12 & VR & \\
\hline $18-7.58 \mathrm{~cm}$ & 168.30 & VR & \\
\hline
\end{tabular}




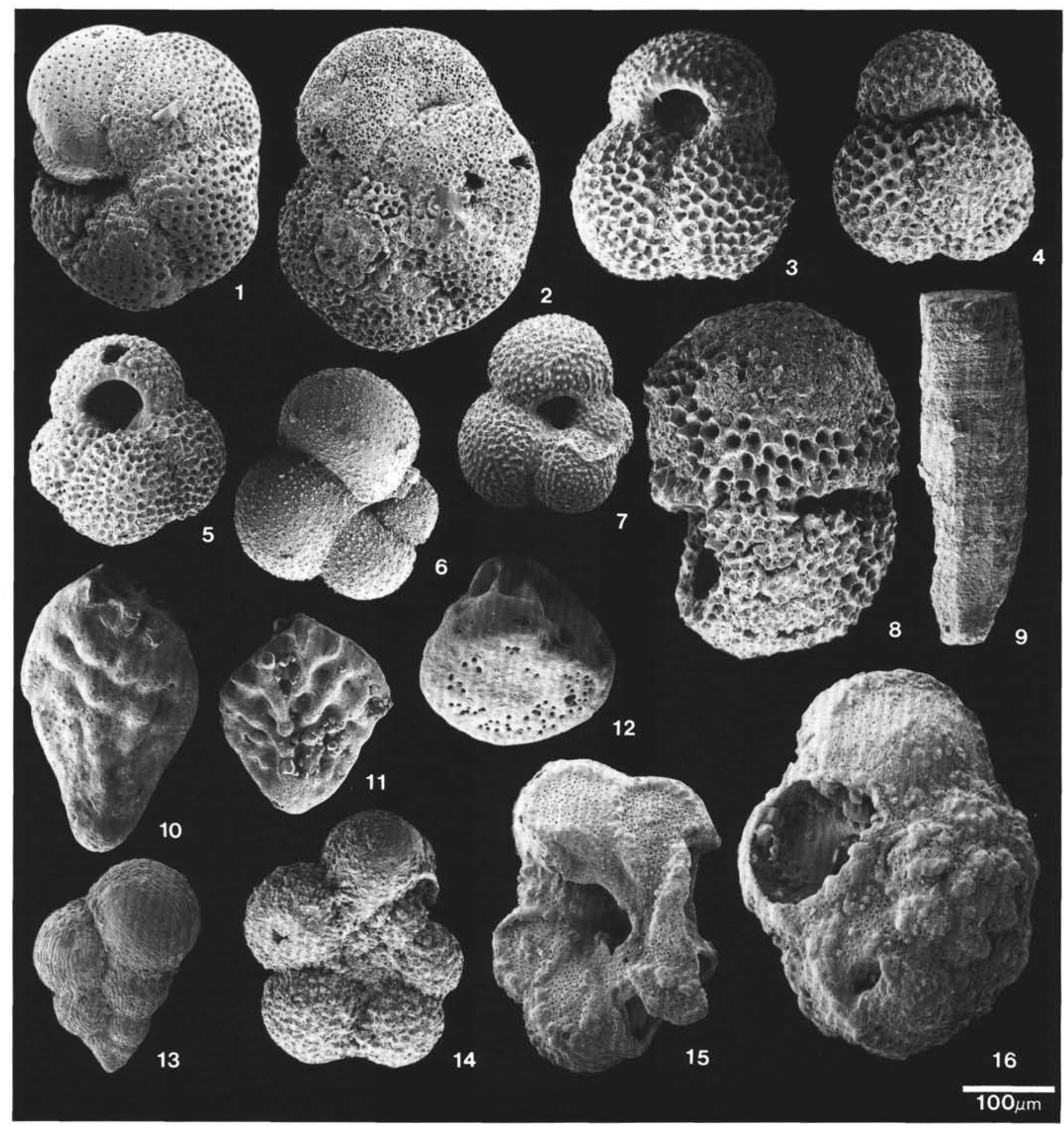

Plate 1. Ice-rafted Tertiary and Cretaceous foraminifers in the Pleistocene section of Leg 104. 1-8. Tertiary planktonic foraminifers. 1-2. Fohsella peripheroronda Blow and Banner, 1966 (N4B-N1O), Sample 104-642B-5-3, 74-78 cm. 3. Globigerinoides subquadratus Brönnimann, 1954 (N4B-N15), Sample 104-642B-7-3, $20 \mathrm{~cm}$. 4. Globigerinoides primordius Blow and Banner, 1962, (N4A-N5), Sample 104-642B-5-3, 74-78 cm. 5. Globoturborotalita woodi (Jenkins, 1960), (N3-N21), Sample 104-642B-5-3, 74-78 cm. 6. Tenuitella clemenciae (Bermudez, 1961), (P19-N4), Sample 104-643A-5-5, $42 \mathrm{~cm}$. 7. Globigerina praebulloides Blow, 1959 (P15-N16), Sample 643A-5-5, $42 \mathrm{~cm}$. 8. Globigerinoides trilobus (Reuss, 1850), (N4B-N22), Sample 104-642B-5-3, 74-78 cm. 9-16. Upper Cretaceous fossils. 9. Prism of an Inoceramus shell, Sample 104-642B-3-1, 116 cm. 10. Bolivinoides decoratus decoratus (Jones, 1886), (Campanian-early Maastrichtian), Sample 104-642B-3-1, $116 \mathrm{~cm}$. 11 . Bolivinoides draco miliaris, Hiltermann and Koch, 1950 (late Campanian-late Maastrichtian), Sample 104-642B-5-7, $33 \mathrm{~cm}$. 12. Stensioeina qranulata incondita, Koch, 1977 (Santonian-early Campanian), Sample 104-642B-3-1, $116 \mathrm{~cm}$. 13. Heterohelix striata (Ehrenberg, 1840), (early Campanian-early Maastrichtian), Sample 104-642B-3-2, 44 cm. 14. Globigerinelloides prairiehillensis, Pessagno, 1967 (Campanian-Maastrichtian), Sample 104-642B-3-1, 116 $\mathrm{cm}$. 15-16. Globotruncana bulloides, Vogler, 1941 (Campanian-Maastrichtian), Sample 104-642B-3-1, $116 \mathrm{~cm}$. The material is stored in the collection of the Geologisch-Paläontologisches Institut und Museum, Kiel, FRG, registration numbers 3596-3611. 